\title{
Gastrointestinal Secretory Induction
}

National Cancer Institute

\section{Source}

National Cancer Institute. Gastrointestinal Secretory Induction. NCI Thesaurus. Code C41484.

Gastrointestinal Secretory Induction involves stimulation of oral, gastric, or intestinal fluid release from cells into the lumen of the gastrointestinal (GI) tract. Stimulation aids digestion and absorption of nutrients as well as protection and lubrication of the GI tract. 